\title{
ESTETIC EXPRESSIONS OF JEPARA CARVING IN EFFORTS TO DEAL WITH THE MARKET DEMANDS
}

\author{
Muhajirin ${ }^{1}$ (muhajirin@uny.ac.id, Universitas Negeri Yogyakarta)
}

\begin{abstract}
The demands of consumers that always evolving makes Jepara craftsmen have to adjust themselves. This is reflected in the aesthetic expression of products that are no longer homogeneous. The purpose of this paper is to analyze the aesthetic expression of Jepara carving art in an effort to face global challenges. Data obtained through interviews and direct observation in the field. The results of the study show that the carving that has now undergone a change due to adjusting to the demands of consumers and the times. European market dominance influenced European-style furniture so that the expression of Jepara carving tends to be European. However, it also developed a carving motif not fixated on the usual themes that were made in the form of motifs with stylized forms of flora fauna, but now also developed geometric and minimalist designs. There is also a simplification of a form into another form, such as by simplifying carving motifs to serve consumers who want products that are not too full of carvings. This consumer demand motivates craftsmen to always do innovation, so consumers are accommodated and served the satisfaction of their aesthetic taste and craftsmen fulfilled their economic needs.
\end{abstract}

Keywords: Aesthetic expression, Jepara carving, market demands

\section{PENDAHULUAN}

Seni ukir Jepara telah membudaya di kalangan masyarakat Jepara sejak jaman dahulu kala, dan telah mengalami perkembangan dan perubahan yang disebabkan oleh tuntutan pasar global. Perubahan sosial budaya yang terjadi di kalangan perajin ukir Jepara karena adanya kontak dengan budaya lain (budaya asing). Ada tiga faktor yang dapat mempengaruhi perubahan sosial yakni: (1) tekanan kerja dalam masyarakat; (2) keefektifan komunikasi; (3) perubahan lingkungan alam.Kebudayaan adalah suatu model pengetahuan yang dijadikan pedoman atau pegangan oleh manusia untuk bersikap atau bertindak dan beradaptasi dalam menghadapi lingkungannya untuk dapat melangsungkan kehidupannya (Suparlan 1983:67).
Pada bagian yang lain muncul hal-hal yang membuat masyarakat perajin ukir menjadi lepas dari yang seharusnya dipertahankan dan menjadi karakter atau ciriciri yang menandakan bahwa produk atau karya tersebut hasil dari buatan masyarakat Jepara. Sebagaian masyarakat Jepara kurang menyadari akan hal tersebut sehingga produk karya yang berkembang tidak bercirikan Jepara tetapi banyak produk karya yang mengikuti tren pasar dan melayani pesanan konsumen.

Menggunakan pemikiran Rohidi (1993) asumsi teoretis yang dapat dikemukakan untuk menjelaskan kondisi perajin seni ukir kayu adalah bahwa mekanisme budaya yang digunakan para perajin untuk tetap dapat mempertahankan dan memberlanjutkan usaha tersebut antargenerasi, dimungkinkan karena adanya pranata sosial dalam keluarga 
melalui proses enkulturasi, yaitu suatu mekanisme budaya untuk mengasuh anak dan mengenalkan, serta mewariskan pengetahuanpengetahuan, nilai-nilai, keyakinan-keyakinan, dan keterampilan-keterampilan kepada generasi penerusnya. Melalui pranata sosial tersebut, para generasi penerus sadar atau tidak, langsung atau tidak, dapat mempelajari dan memiliki pengetahuan, nilai, keyakirian, dan keterampilan untuk dipertahankan dan diberlanjutkan.

Model-model pengetahuan itu digunakan secara selektif oleh warga masyarakat pendukungnya untuk berkomunikasi, dan menghubungkan pengetahuan, dan bersikap serta bertindak dalam rangka bukan saja untuk memenuhi kebutuhan hidup yang diperlukan (Geertz, 1973; Suparlan, 1984) melainkan juga dalam mengatasi setiap tantangan kompetisi hidup yang dihadapi.

\section{MOTIF UKIR JEPARA}

Motif ukir sebagai satu dari sekian wujud budaya masyarakat Jepara, keberadaanya tidak bisa dipisahkan. Sosiohistoris menunjukkan realitas kultural, ekonomi, dan politik yang dibentuk oleh dimensi ruang dan waktu. Ruang dan waktu ini telah diisi oleh perajin untuk terus bertahan dalam proses berkarya. Kegiatan dibengkel mebel (brak) dan showroom di sepanjang jalan penuh mebel berukir yang membuat konsumen akan terkagum-kagum.

Kerajinan ukiran kayu Jepara yang terlihat di sepanjang jalan itu bukannya melalui proses yang singkat dan mudah. Di balik layar, berpasang-pasang tangan yang ahli dan terampil turut andil dalam menciptakan mahakarya yang indah itu. Setiap proses pengerjaannya dari mulai mempersiapkan bahan dasar kayu hingga pemasaran barang jadi merupakan denyut nadi yang menggerakkan perekonomian Jepara .

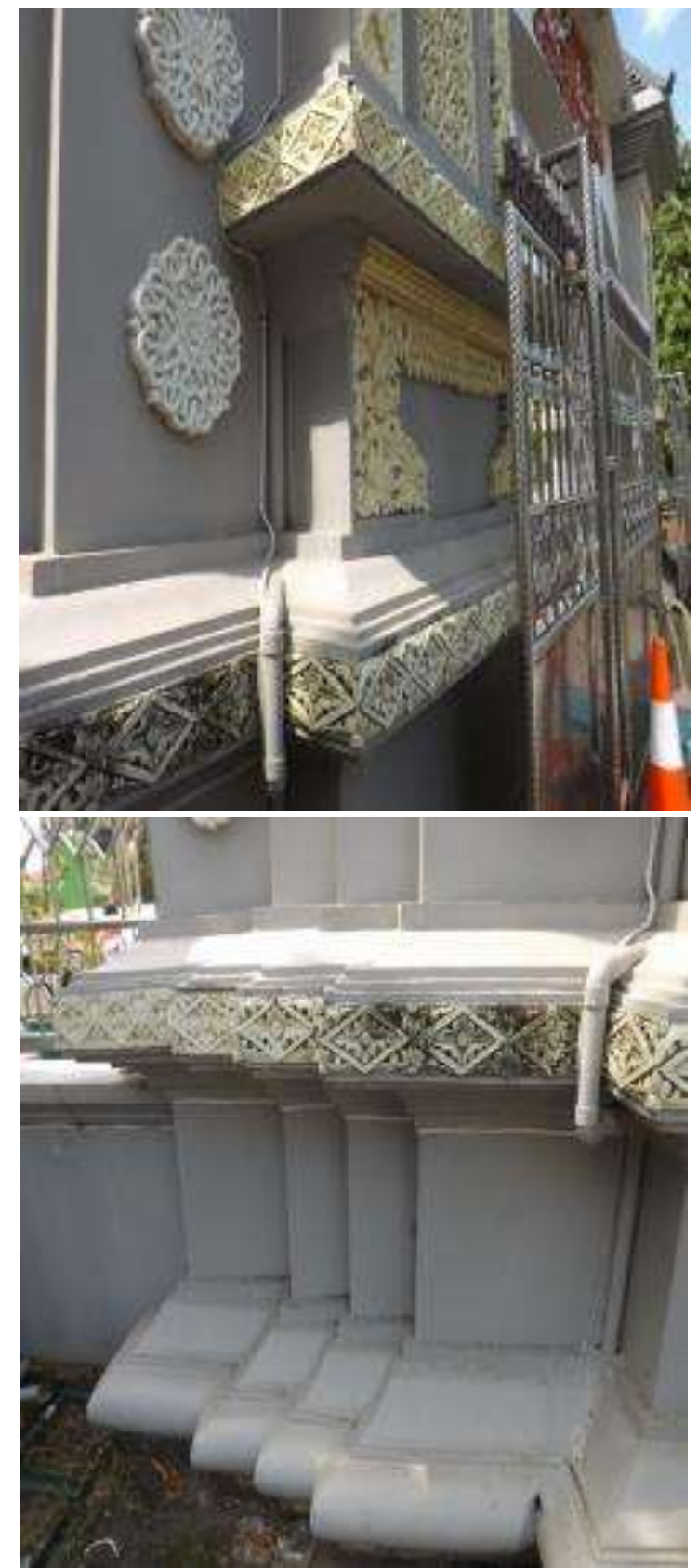

Gambar 1. Ornamen ragam hias yang diterapkan pada Gapuro masuk Masjid Agung Baitul Makmur Jepara Sumber. Dokumentasi peneliti

Desain motif ukir yang diciptakan memiliki nilai estetis dan dari sisi penerapannya menampakkan garapan yang tepat dan berkualitas. Desain motif ukir dalam menghias mengisi ruang-ruang kosong juga diterapkan pada bangunan-bangunan seperti makam, masjid atau rumah-rumah. Motif ukir ini tidak berdiri sendiri secara utuh, 
keberadaannya menempel pada berbagai karya seni. Secara tidak langsung menunjukkan motif ukir Jepara sangat berperan. Motif ukir yang dihasilkan oleh masyarakat Jepara mampu memberikan citra bagi wilayah Jepara hingga menjadi "idiom" kota Jepara.
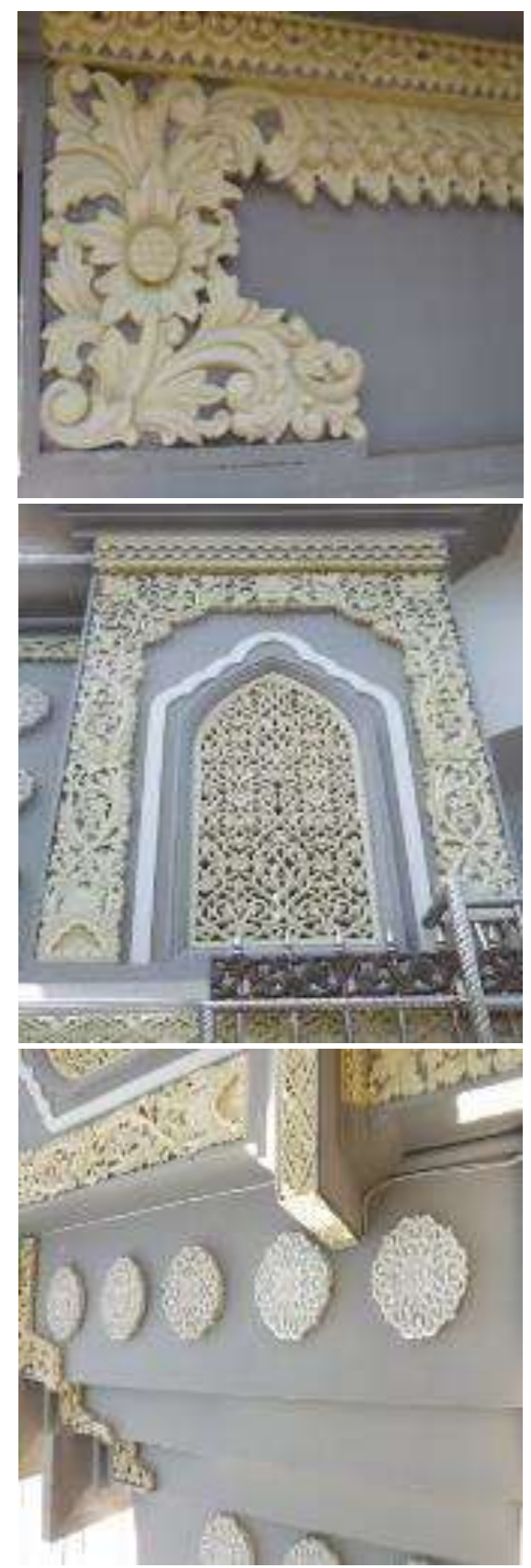

Gambar 2. Bagian-bagian Gapuro masjid Agung Baitul Makmur Jepara yang dihiasi dengan ornamen ragam hias dan diukir

(Dokmentasi peneliti)
Motif ukir pada masjid di Jepara juga menerapkan motif flora yang merupakan ciri khas ukiran asli Jepara yang dipahat dengan teknik krawangan yang ditempelkan pada dinding bangunan maupun elemen ruangnya.

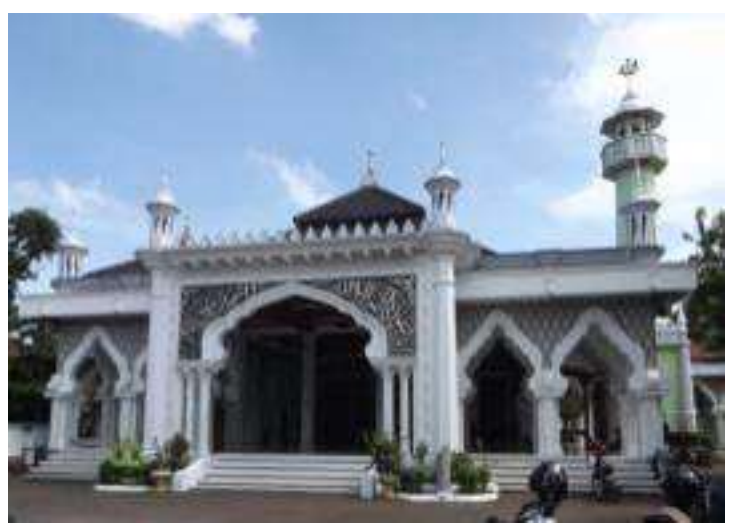

Gambar 3. Masjid Agung Baitul Makmur Jepara (Dokmentasi Peneliti)

Ada pula pengaruh motif ukir yang terdapat pada masjid tua Mantingan yaitu diterapkannya motif anyam-anyaman berbentuk lingkaran (medalion).

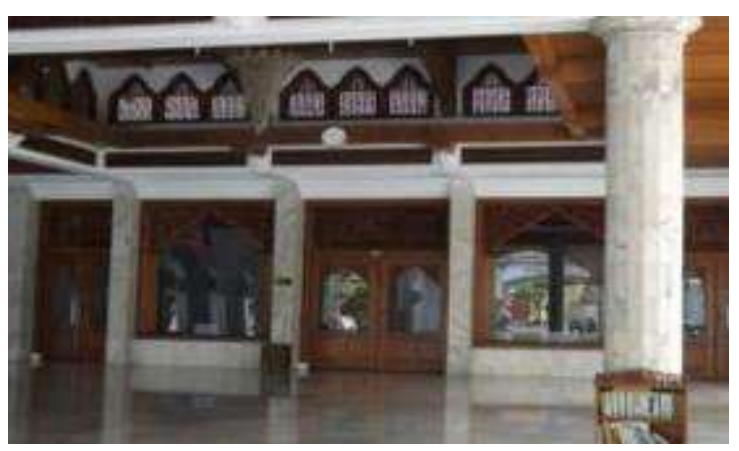

Gambar 4. Serambi Masjid Agung Baitul Makmur Yang Penuh dengan Ornamen ragam hias Jepara (Dokumentai Peneliti)

Selain motif flora, motif ain yang diterapkan adalah kaligrafi yang bertuliskan ayat-ayat Allah, diukir dengan teknik krawangan tembus, sehingga sekaligus embentuk angin-angin (ventilasi). 


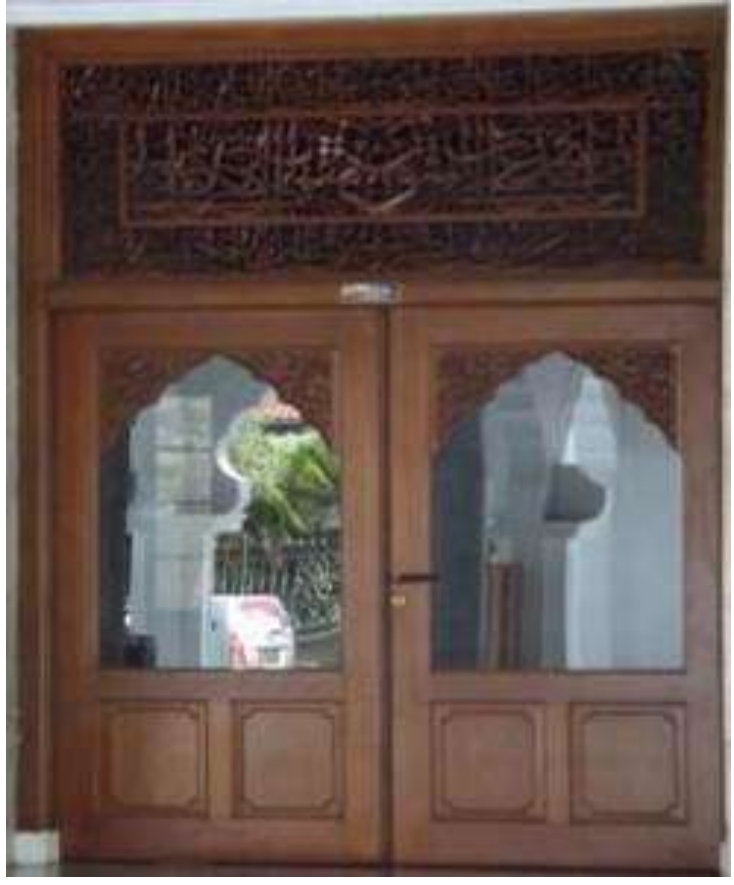

Gambar 5. Salah satu pintu Masjid Agung Baitul Makmur dihiasi dengan Kaligrafi (Dokumentasi Peneliti)

Hiasan berupa motif ukir juga menghiasi elemen bangunan Museum Ukir Jepara seperti gambar 6.8.

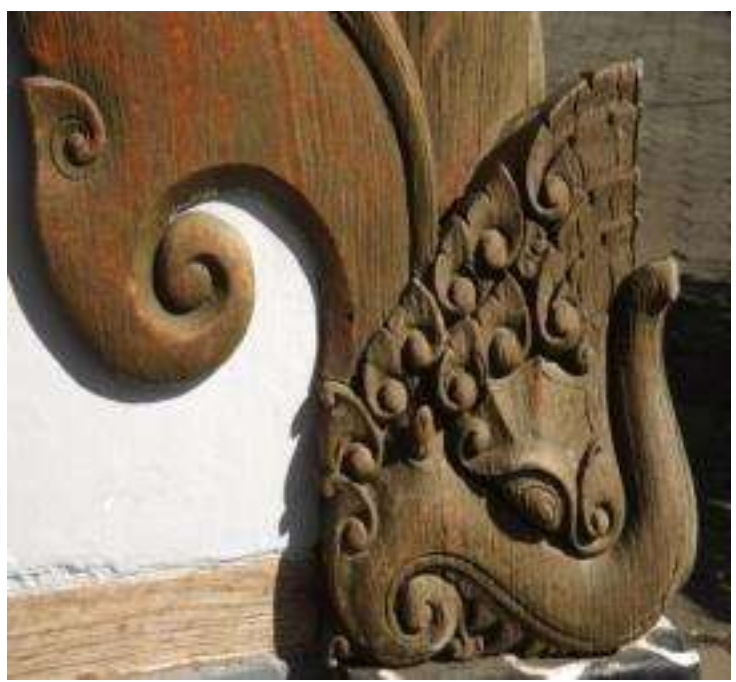

Gambar 6.. Hiasan kepala gajah yang menghiasi sudut bagian luar bangunan museum ukir Jepara (Dokumentasi Peneliti)

Rumah tradisional Jepara juga menerapkan ornamen ukir pada elemen dan struktur bangunannya.

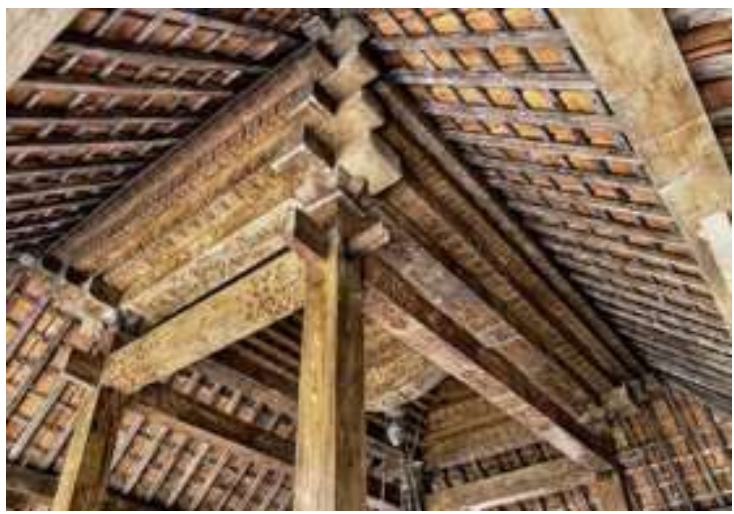

Gambar 7. Ornamen ragam hias yang menghiasi pilar/soko/tiang dan blandar rumah joglo
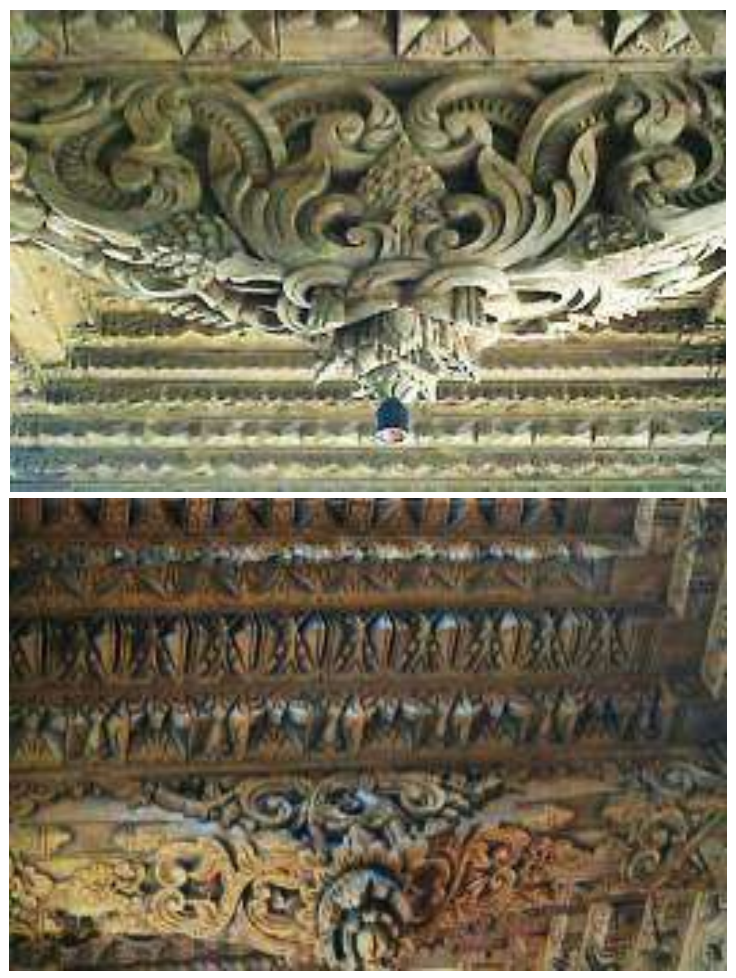

Gambar 8. Ornamen ragam hias yang menghias Dodo Peksi rumah Joglo

Industri mebel ukir Jepara mengalami perubahan yang cepat pada tatanan sosial. Hal tersebut dialami sebagian besar masyarakat Indonesia akibat dari berkembangnya sistem kapitalisme. Perubahan tersebut berdampak pada tumbuh pesatnya perekonomian sebagai dampak dari meningkatnya aktivitas industri mebel, khususnya pelaku mebel ukir yang menekuni usahanya dengan tujuan perdagangan. saat-saat permintaan pasar mebel ukir berlimpah. Banyak mobil dan 
sepeda motor dengan merek keluaran terbaru dimiliki para pengusaha dan perajin. Pertama kali iklan mobil atau sepeda motor ditayangkan oleh televisi, sehari kemudian produk yang sama pasti sudah muncul di jalanan kota Jepara. Begitu pula yang terjadi dengan bangunan rumah penduduk.

Bangunan di sepanjang jalan yang semula masih sangat sederhana dengan lantai tanah mulai digantikan dengan bangunan semen bahkan bertingkat dengan pilar bergaya Romawi yang juga sedang disukai masyarakat. Begitulah seni ukir Jepara, tak hanya bisa dinikmati sebagai benda hiasan, tapi juga mampu mengukir denyut nadi perekonomian Jepara, mengukir pesona dan kebudayaan Jepara, dan juga mengukir kepribadian rakyatnya.

\section{KEMAMPUAN TEKNIK MENGUKIR MASYARAKAT JEPARA}

Penguasaan keterampilan ukir mengalir secara turun temurun pada diri pelaku mebel ukir Jepara kepada anakanaknya ataupun siapapun yang ingin menimba ilmu. Hal ini tentunya tidak terlepas dari sistem sosial yang berlangsung di masyarakat dalam praktik transformasi keterampilan. Masyarakat Jepara pada masa lalu sesungguhnya sudah terbuka dalam menerima calon ahli ukir dari berbagai daerah . Perajin sudah memiliki modal yang menonjol pada kehalusan ukiran dan teknik khas yang dipergunakan dalam menghasilkan poduk ukiran. Karya mebel ukir yang baik umumnya dapat diukur dari kualitas teknis pekerjaannya. Sampai saat ini sistem pewarisan ukir masih tetap dapat mempertahankan kekhasan gaya dan corak, teknik ukir, dan alat-alat yang dipergunakan.

Pemerintah Daerah Kabupaten telah berupaya memusatkan keberadaan sentrasentra ukir untuk mempermudah pembeli mencari barang sehingga produksi semakin efisien. Mulai dari sentra relief, patung, gebyok, almari, dan lain-lainnya. Sentra-sentra yang dimaksud diantaranya adalah:

\section{Mulyoharjo}

Mulyoharjo adalah sebuah desa di kecamatan Jepara Kabupaten Jepara. Desa Mulyoharjo juga dikenal sebagai sentra industri seni patung dan ukir kayu dan merupakan cikal bakal dari seni ukir Jepara . jaman dahulu terkenal dengan ukiran Macan Kurung

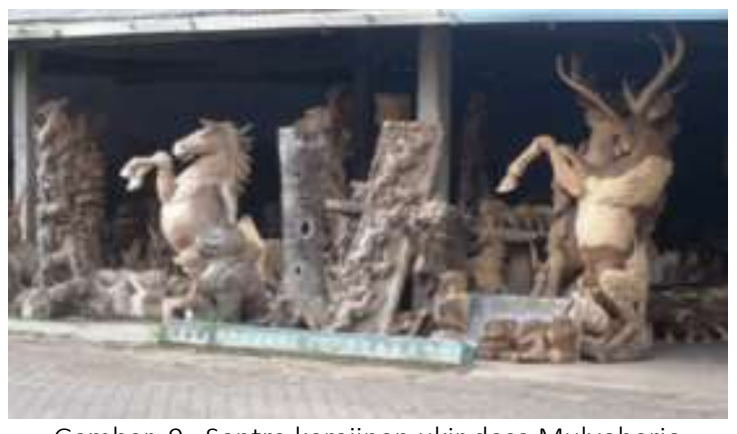

Gambar 9. Sentra kerajinan ukir desa Mulyoharjo

Jadi Sentra kerajinan di Mulyoharjo Jepara mengkhususkan diri pada ukiran berbentuk tiga dimensi (patung) baik berupa patung bentuk hewan maupun manusia. Ini yang menjadi perbedaan dengan sentra kerajinan ukir yang lain.

\section{Sentra Ukir Relief di Desa Senenan}

Selain Mulyoharjo, sentra kerajnan ukir di Jepara yang lain adalah Desa Senenan, yang merupakan sentra perajin seni ukir relief. Kemampuan perajin Senenan dalam membuat relief sangat mengagumkan karena dari sebuah papan kayu utuh kemudian dipahat sedemikian rupa berubah wujud menjadi relief gambar tiga dimensi yang benar-benar hidup. 


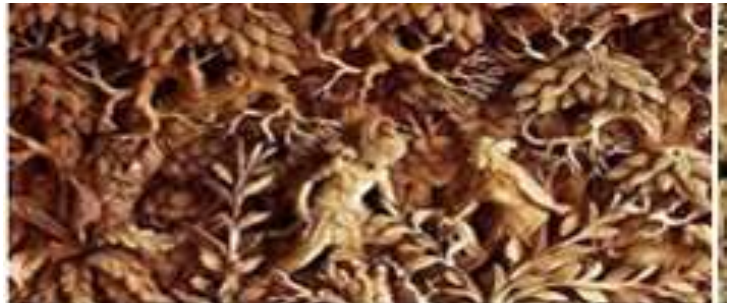

Gambar 10. Relief-relief bertema cerita wayang hasil

karya perajin ukir Senenan pada masa lalu

Desain awal yang dibuat perajin ukir Serenan adalah relief bertema Wayang dengan cerita Mahabarata dan Ramayana, pemandangan, cerita rakyat seperti Djoko Tarub, kegiatan masyarakat seperti Gerobak Sapi, Penjual Sate, motif rumah tradisional, dan motif flora fauna. Relief tersebut dibuat dengan relung dan ceruk yang dalam sehingga kesan tiga dimensi dari relief itu tampak nyata.

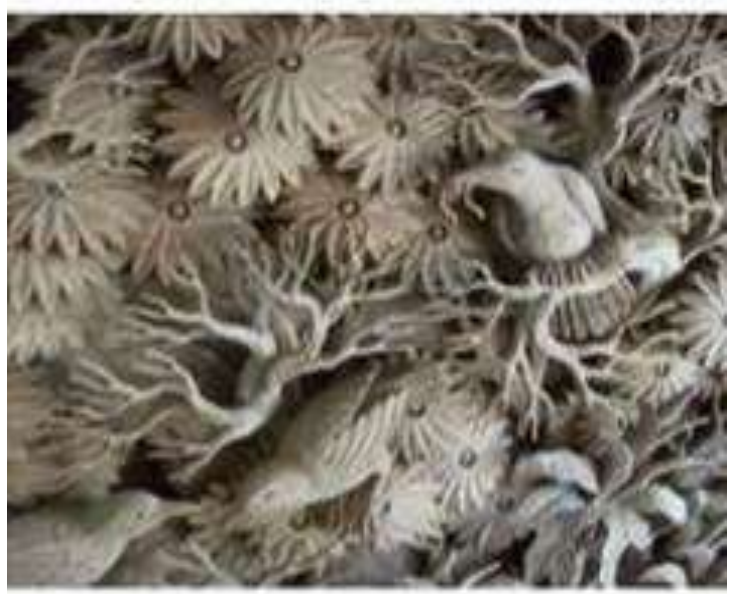

Gambar 11. Relief-relief bertema fauna hasil karya perajin ukir Senenan pada masa lalu

Seiring perkembangan jaman, desainnya pun kini tidak terpaku pada tematema yang biasa dibuat, akan tapi semakin berkembang tidak hanya gambar pemandangan saja tetapi berkembang dengan desain dimensi yang lain yang mengikuti perkembangan jaman dan konsumen. Relief pada saat sekarang sudah mengalami perubahan karena menyesuaikan diri dengan tuntutan konsumen dan perkembangan jaman . Tema yang ditampilkan adalah kehidupan alam satwa, motif flora fauna dari motif asli Jepara (ada pula pengaruh ornamen Mesjid mantingan) yang dikembangkan dengan menggunakan teknik ukir relief susun tindih tembus dengan kemampuan kekriyaan (craftmanship) tinggi.

Inilah diantaranya karya-karya ukir relief pengembangan, hasil karya masyarakat perajin dari desa Senenan;
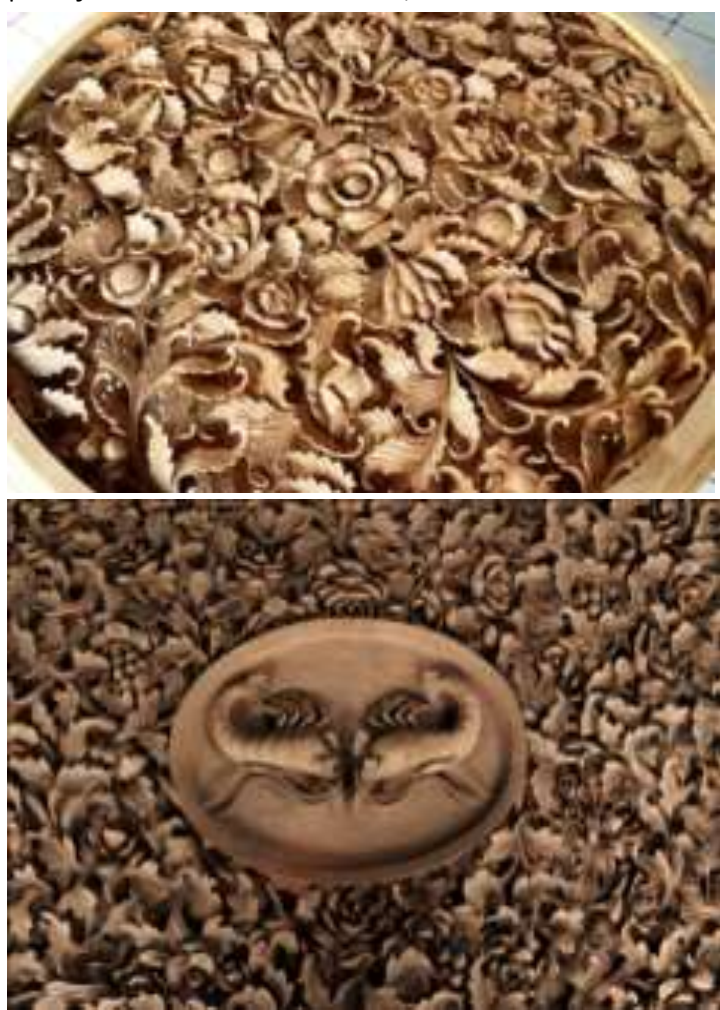

Gambar 12. Motif pengembangan berupa motif flora yang dipengaruhi oleh motif di mesjid Mantingan

Selain mengerjakan motif yang merupakan pengembangan dari yang sudah ada perajin ukir di Senenan juga melayani pesanan konsumen yang datang dengan membawa desain yang harus dikerjakan sesuai dengan ketetuan peesan. Salah satu contoh adalah Relief bertema The Last Supper (perjamuan terakhir). Meskipun masyarakat jepara adalah masyarakat yang agamis dan taat beribadah, pada kenyataannya pesanan yang bernuansa peribadatan atau menyimbolkan figur dari agama lain tak segan untuk mereka buat, sepanjang itu merupakan pesanan konsumen dengan harga yang sesuai. 


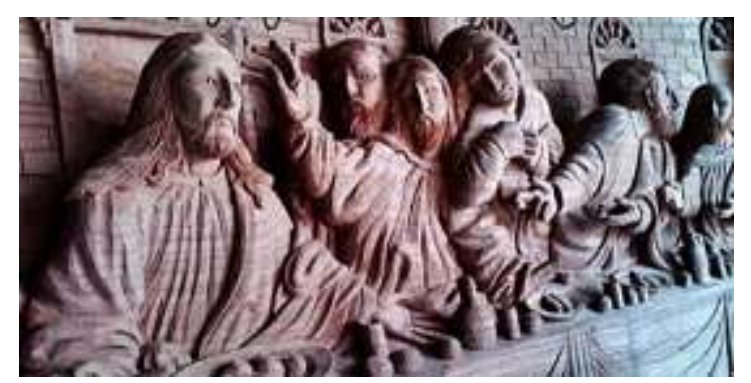

Gambar 13. Ukiran relief bertema The Last Supper (Perjamuan terakhir) pesanan konsumen

Perajin Jepara memiliki potensi dari keunggulan talenta ukir yang unik yang jarang ditemui di daerah lain. Selain sikap kejujuran dan etos kerja yang tangguh atau ubet (bahasa Jawa, berarti ulet), perajin Jepara juga mempunyai potensi sebagai pekerja yang mandiri dengan kepercayaan diri yang kuat tanpa meninggalkan keyakinan dan sikap mental spiritual. Nilai dasar inilah yang menumbuhkan sikap percaya diri yang kuat dalam berwirausaha dan selalu berkomitmen untuk menghasilkan karya mebel yang berkualitas sesuai penerimaan konsumen.

\section{Sentra Ukir Gebyok di Desa Blimbingrejo}

Gebyok adalah salah satu furniture khas Jepara berupa partisi penyekat ruangan pada arsitektur khas Jepara yang pada umumnya terbuat dari bahan kayu jati. Biasanya dipergunakan untuk menyekat antara ruang seperti ruang tamu atau ruang keluarga dengan kamar-kamar di rumah adat. Gebyok pun bisa dipasang sebagai pemanis pendopo di salah satu sisinya untuk menuju ke rumah adat.

Gebyok Ukir Jepara sangat cocok untuk dijadikan pintu rumah ataupun pintu masjid sehingga semakin membuat rumah semakin menarik dan unik. Desa Blimbingrejo sudah menjadi Sentra Ukir Gebyok sejak tahun 1980-an hingga sekarang. Saat ini di desa tersebut sudah ada 90 orang perajin, dengan jumlah total pekerja mencapai lebih dari 300 orang. Karena dari setiap perajin besar bisa memperkerjakan 6-14 orang, sedangkan untuk perajin kecil biasanya memperkerjakan sebanyak 2-3 karyawan saja

Gebyok yang baik adalah yang ukirannya detail, halus, memiliki ukiran dalam dengan tingkat kesulitan tinggi, tiga dimensi, kualitas kayu yang digunakan sebagai bahan baku gebyok pada umumnya memang merupakan jenis kayu yang tahan cuaca, kayu yang sudah tua sehingga cenderung lebih kuat dan awet untuk dijadikan dekorasi yang indah menawan. Dengan segala keunikannya, gebyok sebagai partisi khas Jawa yang memiliki nilai estetika, bernilai seni tinggi tidak akan ditemukan di tempat atau daerah lain kecuali di tanah Jawa seperti di daerah Jepara . Pada dasarnya gebyok berfungsi sebagai partisi penyekat antar ruangan, bisa juga dipakai untuk pintu masuk dalam rumah, ada juga yang memajangnya di gerbang pintu masuk.

Aplikasi gebyok saat ini tidak lagi menjadi elemen yang terlalu kaku ukurannya seperti dalam rumah-rumah adat Jawa. Kini gebyok menjadi warisan budaya Indonesia yang tidak lekang oleh jaman. Gebyok penuh metafor dan pesan tentang kebijakan hidup tentang kesejahteraan hidup. Sejahtera bukan di dunia saja melainkan di akhirat.

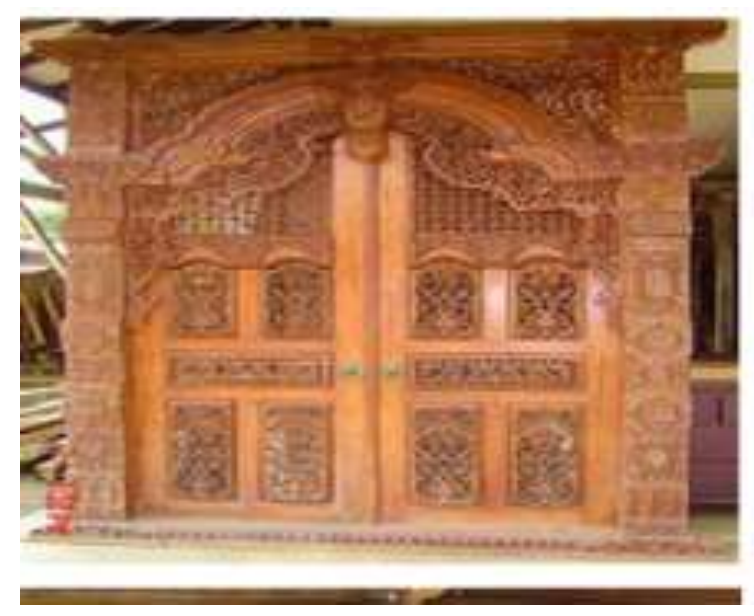

Gambar 14. Beberapa bentuk Gebyok dari perajin desa Blimbingrejo

Motif atau ragam hias khas Jepara yang diterapkan pada Gebyok merupakan 
ekspresi dari pada bentuk-bentuk tanaman yang menjalar. Tiap ujung relungnya menjumbai daun-daun krawing yang sangat dinamis. Biasanya di tengah jumbai terdapat buah-buah kecil-kecil yang berbentuk lingkaran. Ciri ragam hias ini dapat dilihat dengan adanya tangkai relungnya panjangpanjang melingkari di sana-sini membentuk cabang kecil, berfungsi sebagai mengisi ruang / pemanis.
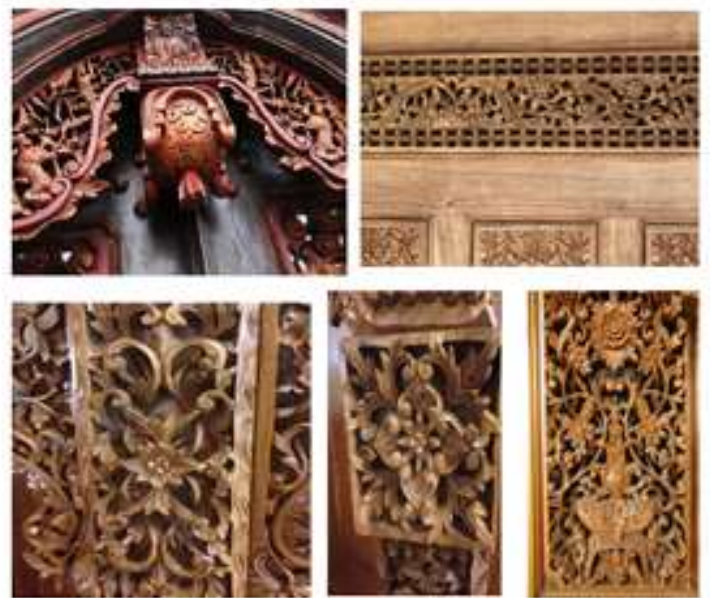

Gambar 15. Motif atau ragam hias yang diterapkan pada gebyok dan rumah joglo.

\section{Sentra Ukir Almari di Desa Bulungan}

.Warga Desa Bulungan mayoritas bekerja sebagai pembuat produk mebel ukir terutama berbentuk almari. Banyaknya masyarakat yang berprofesi sebagai perajin almari, membuat Pemerintah Kabupaten Jepara mencanangkan Desa Bulungan Kecamatan Pakisaji sebagai kawasan industri mebel almari di Jepara. Almari produksi Desa Bulungan yang selama ini sudah diminati berbagai kalangan baik di Pulau Jawa dan luar Jawa. Sektor mebel khususnya almari mampu menyerap banyak tenaga kerja, mulai dari pengusaha kayu, perajin, showroom, jasa angkutan dan lain sebagainya.

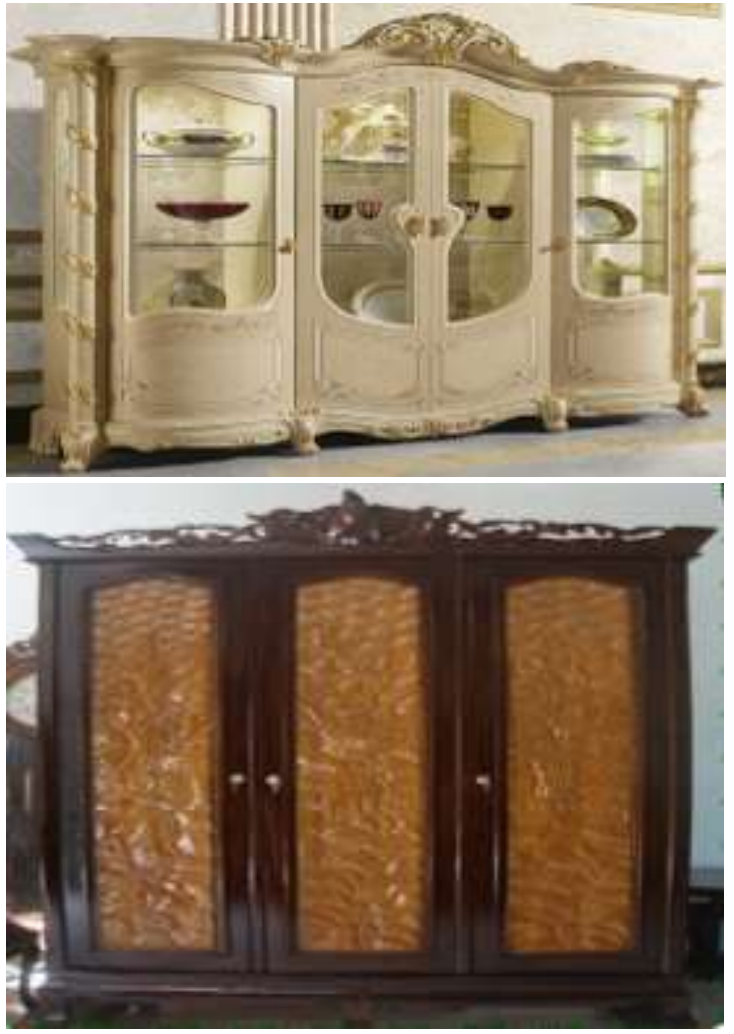

Gambar 16. Almari ukir hasil dari perajin desa Bulungan

Ada banyak varian produk almari yang dihasilkan para perajin Desa Bulungan, baik berupa almari pakaian, buffet, almari hias, maupun almari rak buku. Beberapa tipenya seperti almari mawar, peluru, majahapit, rahwana, tiara, kanopi, minimalis, tambang, selendang dan lain sebagainya.

Harga tiap almari juga berbeda-beda, tergantung ukuran, kualitas kayu jati yang digunakan, bentuk dan lain sebagainya. Nilai transaksi yang dihasilkan dari sektor ini juga mencapai ratusan juta rupiah tiap bulannya. Selama ini pemasaran almari Bulungan tidak hanya di kota-kota besar di Pulau Jawa saja, namun juga merambah kawasan luar Pulau Jawa seperti Sumatera, Kalimantan, Aceh dan lain sebagainya.

\section{Sentra Ukir Genteng di Desa Mayong Kidul}

Desa Mayong Kidul merupakan sentra kerajinan genteng dengan bentuk ukir-ukiran Jepara yaitu Genteng Makuta, Genteng Gatotkaca, Genteng Krepyak. 


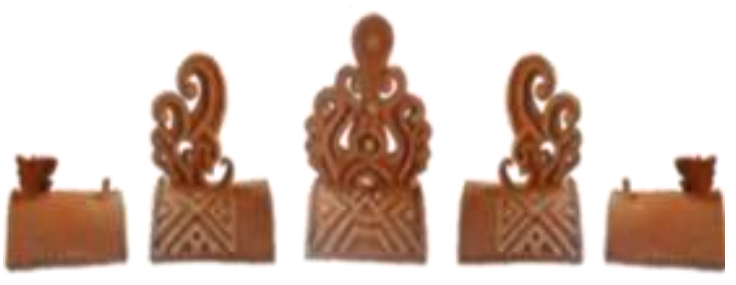

Gambar 17. Genteng dengan motif ukir Jepara produksi masyarakat Mayong Kidul Jepara

Hal yang menarik dari motif ukir Jepara disamping memiliki bentuk yang khas, ada indikasi perwujudan kekuatan pengembangan terhadap mewujudkan karya seni yang menjadi kebanggaan masyarakat Jepara . Tetapi dalam proses pengembangannya bisa dianggap bahwa masyarakat Jepara tidak tahu hasil-hasil kreatif dari para perajin ukir apakah bentuk yang dihasilkan termasuk ke dalam bentuk yang mencirikan bentuk dari motif ukir Jepara, itulah yang menarik kalau melihat dari sisi warisan dan perkembangan bentuk motif ukir. Motif ukir terpengaruh dengan berbagai budaya. Jika melihat hasil-hasil kerja kreatifnya, bentuk yang dihasilkan tetap mencerminkan lokal. Yang dimaksud adalah masih tetap membentuk karakter yang mencirikan visual dari bentuk-bentuk sebelumnya berdasarkan pengalaman masyarakat pendukungnya.

Motif ukir Jepara pernah mengalami puncak kepopuleran, ketika motif ukir diterapkan pada produk mebel ukir yang dihasilkan oleh para perajin. Bahkan hampir semua produk mebel ukir yang dihasilkan dipenuhi dengan hiasan motif ukir. Ini merupakan sedikit peran motif ukir untuk memenuhi keinginan masyarakat guna menunjang keindahan rumah dengan segala produk mebel ukir. Dapat digambarkan motif ukir Jepara berperan besar dalam memajukan kota Jepara dalam proses adaptasi terhadap perubahan jaman yang terus berkembang.
Pengembangan motif ukir dalam mencapai puncak kepopulerannya juga mengingatkan akan peran pemerintah yang sering menyerukan keindahan motif ukir. pengembangan desain motif ukir yang tetap bertahan hingga saat ini oleh para perajin . Desain motif ukir Jepara dapat diamati sebagai cerminan kontruksi sosial dalam hubungannya dengan identitas kultural dan tradisi. Pewarisan budaya (transmission of culture) merupakan tindakan proses mewariskan budaya dari satu generasi ke generasi masyarakat berikutnya melalui proses pembudayaan. Sesuai dengan spirit dan budaya sebagai milik bersama masyarakat, maka unsur kebudayaan itu menyatu dalam individu masyarakat dengan jalan diwariskan atau dibudayakan melalui tindakan proses belajar budaya. Tindakan proses pewarisan budaya dilakukan melalui proses enkulturasi (pembudayaan) dan proses sosialisasi (belajar atau mempelajari budaya). Pewarisan budaya pada dasarnya dilaksanakan melalui empati lingkungan keluarga, masyarakat, sekolah, lembaga pemerintahan, perkumpulan, institusi resmi, dan media massa. Melalui tindakan proses pewarisan budaya maka terbentuk manusia yang memiliki kepribadian selaras dengan lingkungan alam, sosial dan budayanya disamping kepribadian yang tidak selaras (menyimpang) dengan lingkungan alam, sosial dan budayanya.

\section{PROSES KREASI MASYARKAT PERAJIN UKIR JEPARA}

Mayoritas dari komunitas perajin ukir di Sentra ini adalah perajin ukir otodidak atau mereka yang mengukir secara turun-temurun karena faktor lingkungan atau budaya yang berkembang di lingkungan masyarakat tersebut. Pengaruh lingkungan atau alam pada diri perajin ukir di sentra ini sangat dominan. Hal ini bisa dilihat ketika seorang perajin ukir pindah ke daerah lain maka akan sulit bagi 
dirinya untuk mengembangkan kualitas ukirannya. Alam merupakan faktor penentu berkembang atau tidaknya seorang perajin ukir. Kompetisi yang timbul di suatu lingkungan merupakan referensi dan motivasi bagi seorang perajin ukir untuk mengembangkan ide dan gagasan demi terciptanya sebuah ukiran. Kompetesi atau persaingan di dalam sosial masyarakat perajin ukir di Jepara dapat dimakni secara positif guna meningkatkan kualitas produksi sehingga akan menarik konsumen untuk lebih meningkatkan seleksi .

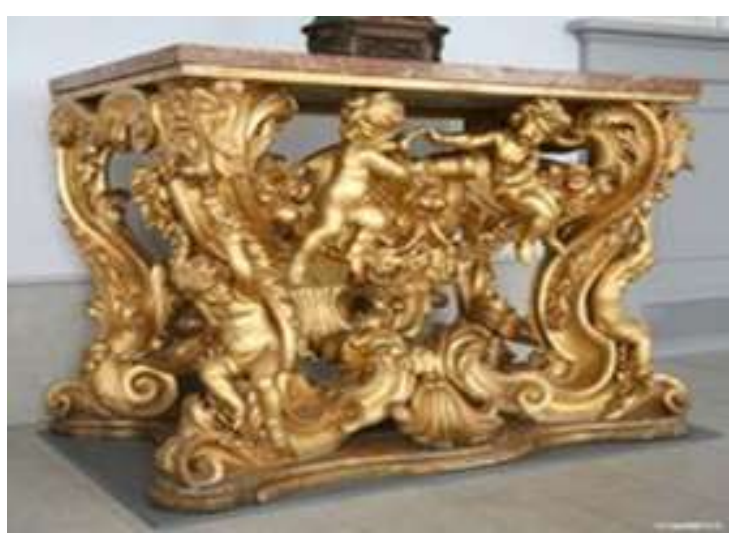

Gambar 18. Produk barang berupa meja hias dengan motif dan corak ornamennya dari Eropa yaitu Baroque Rococo

Karya tersebut diorderkan pada perajin oleh konsumen atau pemesan berupa gambar dari majalah. Konsumen minta dibuatkan barang sesuai order kemudian terjadi transaksi antara konsumen dengan perajin, akhirnya dibuat kesepakatan. Oleh perajin dibuatlah dua barang, dengan asumsi bahwa ketika nanti barang pesanan tersebut diambil oleh pemesan, perajin masih punya barang tersebut, dengan harapan apabila ada tamu atau konsumen lain yang datang tertarik kemudian memesannya.

Berikut adalah produk-produk yang berkembang dan diproduksi oleh masyarakat perajin dan biasanya produk tersebut laris dipasaran.
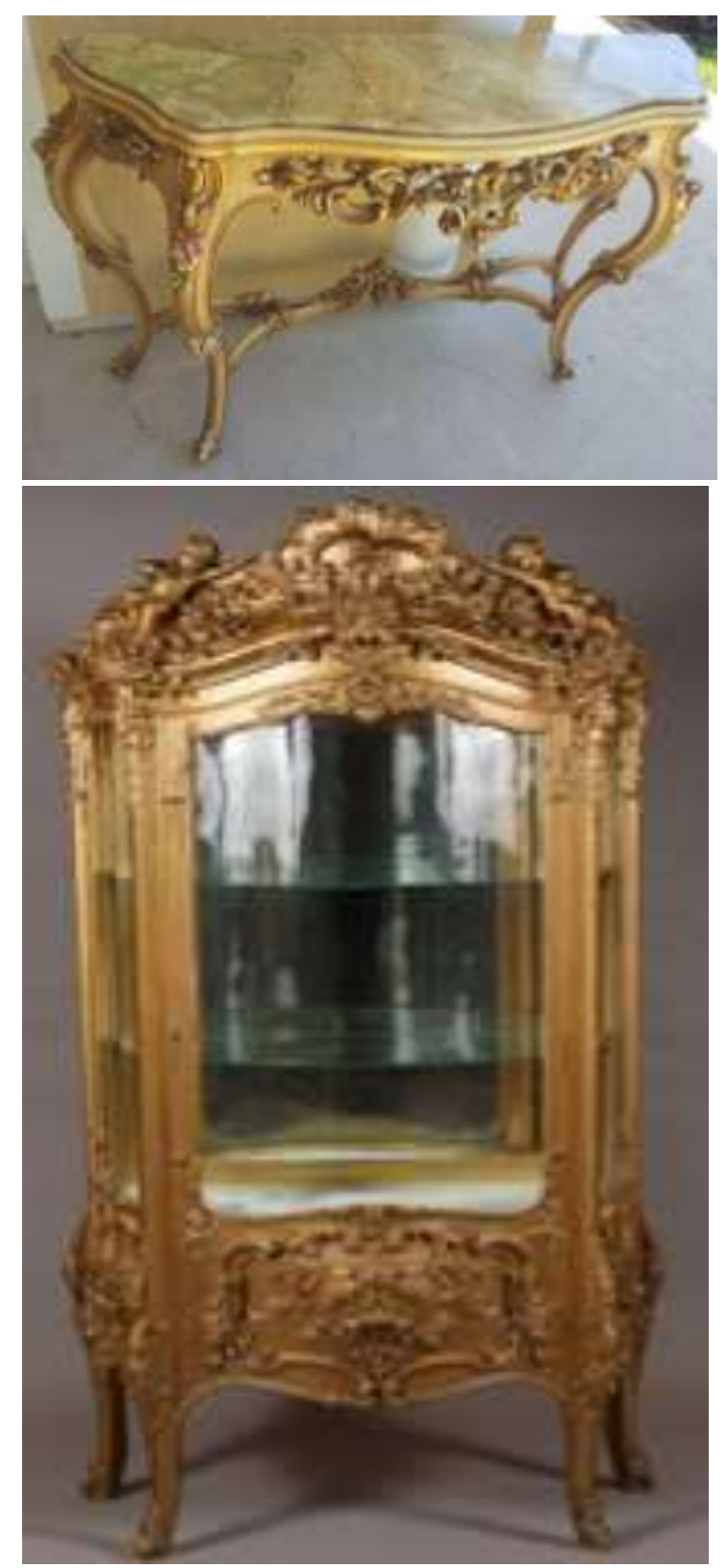

Gambar 19. Karya yang dihasilkan perajin dari pesanan

Model dan ukuran yang diproduk oleh masyarakat perajin sangat bervariasi; bentuknya ada yang dibuat lebih ramping kemudian motif ragam hiasnya dikurangi atau dibuat lebih simpel sehingga dari segi harga bisa terjangkau oleh konsumen.Untuk mengejar harga supaya konsumen menjangkau, terkadang bahan pokok kayu perlu juga dikreasikan kalau tidak dikatakan disiasati atau dikurangi dan diganti dengan bahan yang lebih murah. 


\section{KEMAMPUAN PERAJIN UKIR JEPARA MERESPON PESANANAN}

Perajin ukir Jepara dikenal mampu merespon dengan cepat apapun pesanan konsumen, meskipun pesanan yang diminta hanya berupa gambar (dalam bidang datar dua dimensi) . Kemampuan membaca gambar dan mewujudkannya ke dalam bentuk tiga dimensi dengan detailnya yang sangat presisi merupakan ketrampilan yang jarang ditemui di tempat lain.

\section{Menguasai, memahami dan membaca gambar}

Pesanan dari konsumen biasanya berupa gambar di atas kertas, dengan ukuran yang tidak terlalu rinci. Dari gambar tersebut perajin ukir mampu memahami bentuk, kedalaman ukiran, dan detail-detail lainnya.

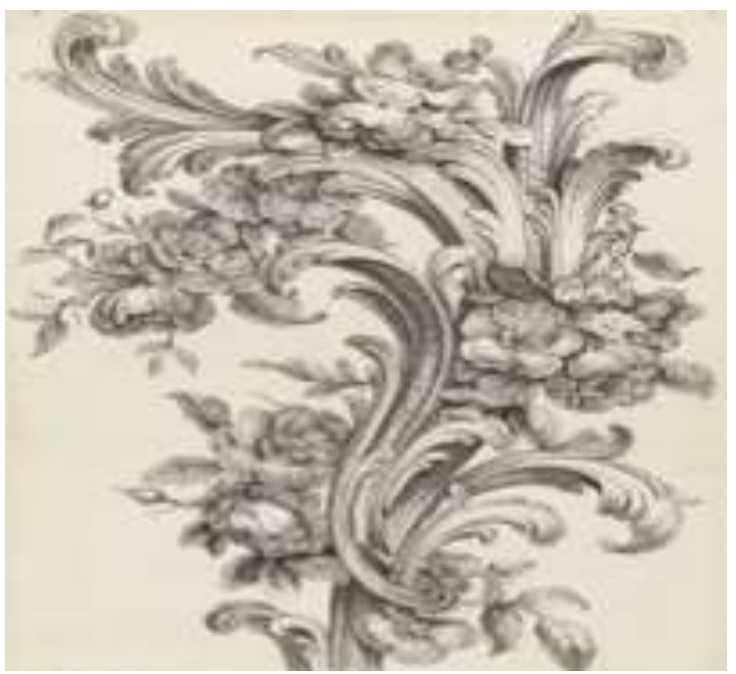

Gambar 20. Beberapa motif hias masih dalam bidang datar (gambar)

\section{Mewujudkan Gambar motif ragam hias menjadi ukiran}

Setelah membaca gambar, perajin kemudian mewujudkan gambar tersebu ke dalam bentuk ukiran tiga dimensi.

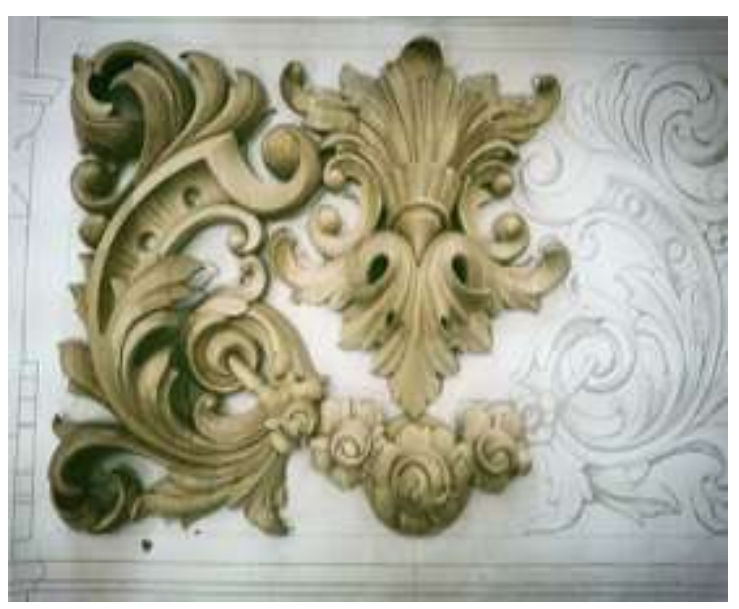

Gambar 21. Mewujudkan gambar motif ragam $\mathrm{h}$ ias menjadi ukiran yang berdimensi

\section{Mewujudkan motif ragam hias pada benda} pakai

Perajin juga menerapkan ukiran pada benda-benda pakai, seperti furnitur, elemen arsitektur, maupun elemen estetis lainnya. Semua produk yang dibuat tersebut semua dimulai dengan membuat gambar terlebih dahulu pada kertas dengan skala 1:1 kemudian dipindah pada papan kayu yang akan diukir atau langsung ke produk yang akan diterapkan ukiran.

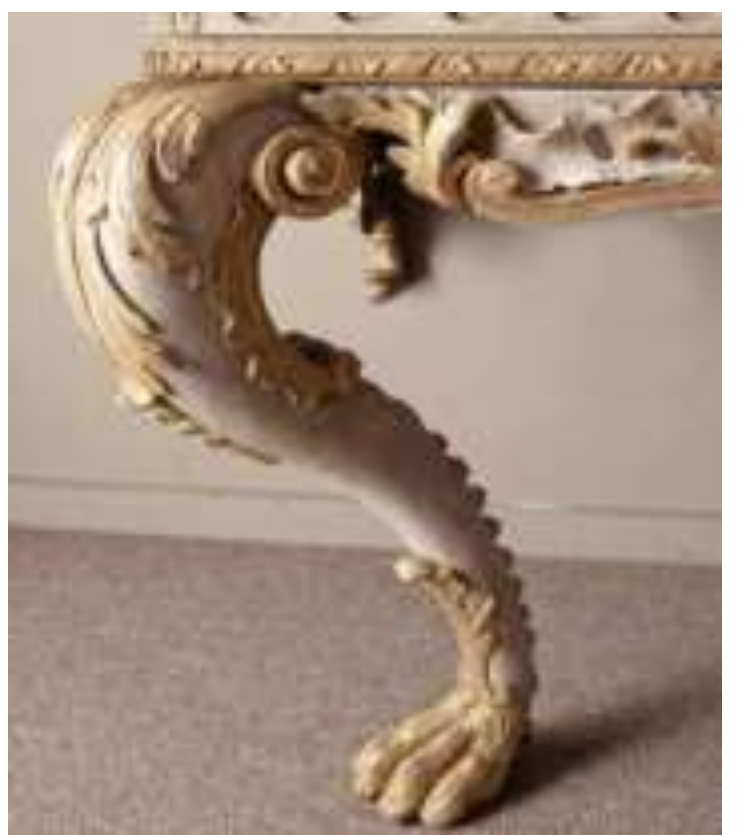




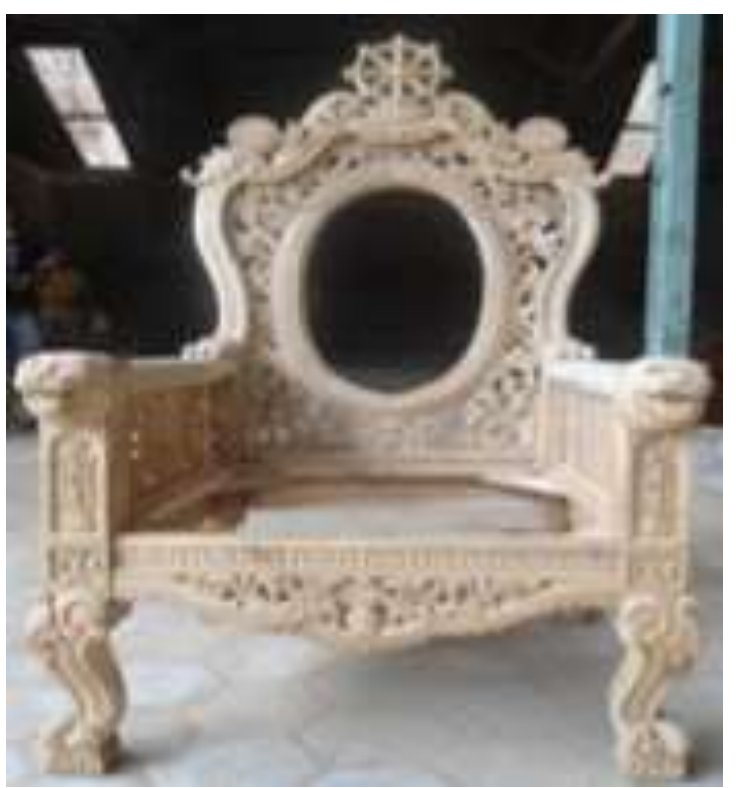

Gambar 22. Mewujudkan gambar motif hias pada kursi

PENUTUP

Keahlian pengukir Jepara ini, didapatkan turun-temurun dari nenek moyang pengukir. Untuk menciptakan motif ukiran yang baik dan menarik tidaklah mudah, karena perajin harus mempunyai jiwa seni yang tinggi. Untuk itu, pengukir membutuhkan keahlian dan ketelatenan yang tinggi. Selain itu, kreativitas dari si pengukir juga sangat diperlukan untuk menciptakan motif ukiran yang selalu inovatif.Tampilan ukiran Jepara selalu terlihat luwes (tidak kaku) dan terlihat rapi sehingga ukirannya menarik dan enak dipandang mata. Keelokan ukiran Jepara tidak pernah luntur dimakan jaman, dipandang dan dinikmati kapanpun akan selalu tetap indah dan mempesona.

Ukiran kayu di Jeparadiproduksi di tempat-tempat yang memang terkenal dengan pengukirnya yang sudah mahir. Dengan tatah dan pahat ukir, perajin ukiran di Jepara membuat bentuk dan motif yang sudah biasa beredar di pasaran, sehingga proses pembuatannya tidak terlalu lama, karena kebanyakan dari mereka sudah sangat hafal. Jika dicermati, motif ukir-ukiran Jepara selalu berubah-ubah mengikuti tren yang berkembang saat ini, jadi motifnya tidak monoton itu-itu saja, dengan kata lain motif ukiran Jepara selalu berubah mengikuti perkembangan jaman. Kalau dulu ukir-ukiran Jepara kebanyakan bermotif rumit (klasik), kini di era modern motif dan model ukiran Jepara dibuat lebih simpel dengan tujuan lebih menonjolkan kesan minimalis sesuai dengan model yang banyak digemari saat ini.

Furnitur ukir Jepara juga dapat mengekspresikan status sosial bagi pemiliknya, dan menandakan bahwa pemiliknya berkelas. Bagi siapa saja yang memiliki mebel ukir Jepara baik kursi, meja, almari, patung, gebyok ukir Jepara, seolah-olah status sosialnya meningkat atau tinggi dan memperlihatkan status ekonomi pemilik rumah.

\section{DAFTAR PUSTAKA} 1990. Seni Kerajinan Mebel Ukir Jepara. Yogyakarta: Kanisius.

"Industri Mebel Jepara" dalam .(http://amkri.org/amkri/2016/05/10/ penguatan-

"Prospek Bandung Menuju Kota Jasa di Era Globalisasi dilihat dari sudut

Asa, Mengukir Masa Depan di Sekolah Ukir Jepara. Jumat 22 November 2013 http://m.ayogita bisa. Com./inspirasi/mengukir-masa-depandi-sekolah-ukir-jepara html

industri-mebel-jepara-mendesakdilakukan/?lang=id diakses tanggal 15

Kardinah Reksonegoro. 1978. Tiga Saudara: Kartini, Roekmini, Kardinah. Pemda II Rembang.Kebudayaan.

Pemkab Jepara (2013). Peran Dan Arah Pengembangan Industri Mebel Jepara; Simposium Nasional, "Value Chain of 
Furniture, Other Forest Products and Ecosystem"s

Peraturan Daerah Kabupaten Jepara Nomor 2 Tahun 2011. Tentang Rencana Tata Ruang Wilayah (RTRW) Kabupaten Jepara Tahun 2011-2031

Rohidi, T.R. 1987. Peranan Pendiikan Kesenian dalam Rangka Pembangunan Kebudayaan Nasional (Sebuah Permasalahan). Makalah FPBS IKIP Semarang.

Rohidi, T.R. 1993. "Ekspresi Seni Orang Miskin : Adaptasi Simbolik terhadap Kemiskinan" Disertasi Doktor PPS U.I.

Seminar pekan kebudayaan Jerman Indonesia di Bandung berjudul

Setiawan, Agus. 2010. "Ornamen Mesjid Mantingan Jepara JawTengah Jurnal Siregar, A., Sandi, "Tata Bangunan dan Lingkungan di Kota Bandung" Artikel

Soedarso, Sp. 1998. Perkembangan Desain Produk Industri Kerajinan. Yogyakarta. 